\title{
Use of Internet Technologies by the Tourism Products Consumers in Ukraine
}

\author{
Raisa Kozhukhivska, Olena Sakovska, Svitlana Skurtol, Serhii Kontseba, Viktoriia Zhmudenko
}

\begin{abstract}
The importance of modern information and communication technologies in the economic and social life has steadily increased. The Internet creates new opportunities to provide services and meet needs. Tourism enterprises are interested in making a big profit from their sales and want the customers to give their preferences to them.

The article deals with the peculiarities of Internet use by the tourism services consumers. Determined that the compared to traditional advertising technologies, Internet makes it possible to provide a dialogue with the consumer, to establish feedback and, in terms of investment, it is much cheape. The data representing the social characteristics of the sphere of Ukrainian Internet consumers are generalized. The main reasons and motives for making online purchases by tourism services consumers are indicated. The barriers that hinder the further development of Internet commerce and the promotion of online tourism services have been identified. Quantitative and qualitative research on the use of tourism Internet services in Ukraine has been carried out.

Has been summarized thet the among the main universal reasons that motivate the population to use I-services are: the time-saving; variety of proposals; convenience; overcoming geographical and temporary barriers; finance saving.
\end{abstract}

Keywords: information technologies, Internet, Internet service, tourism, consumer.

\section{INTRODUCTION}

In recent years the importance of modern information and communication technologies in the economic and social life has steadily increased. The Internet creates new opportunities to provide services and meet needs. Tourism enterprises are interested in making a big profit from their sales and want the customers to give their preferences to them.

The tourism services sale using Internet opportunities as one of the important tools of a tourism enterprise brand formation can provide additional benefits in forming a positive image of a tourism enterprise and enhancing consumer loyalty, since Internet allows to provide unlimited amount of information. In this case, the amount of information consumed is determined by the user himself. Compared to traditional advertising technologies, Internet makes it possible to provide a dialogue with the consumer, to

Revised Version Manuscript Received on 15 September, 2019.

Raisa Kozhukhivska, Department of Tourism, Hotel and Restauran Business, Uman National University of Horticulture, Uman, Ukraine. (E-mail: ray80@ukr.net)

Olena Sakovska, Department of Tourism, Hotel and Restaurant Business, Uman National University of Horticulture, Uman, Ukraine. (E-mail: sakovska_lena@ukr.net)

Svitlana Skurtol, Department of Information Technology, Uman National University of Horticulture, Uman, Ukraine. (E-mail: skurtol@i.ua)

Serhii Kontseba, Department of Information Technology, Uman National University of Horticulture, Uman, Ukraine. (E-mail: kontseba@meta.ua) University of Horticulture, Uman, Ukraine. (E-mail: zhvika78@gmail.com)
Viktoriia Zhmudenko Department of Management, Uman National

establish feedback and, in terms of investment, it is much cheaper. Taking into account the above, the study of online sales features and the scope of online services use by consumers of tourism products is a matter of current interest.

\section{LITERATURE REVIEW}

One of the current pressing trends in social reality is the increasing importance of knowledge and the development of new technologies that can transmit information faster, thus forming an increasing share of services in the economy.

A number of researches of foreign and domestic scientists are devoted to the topic of Internet use by tourism products consumers. In particular, the studies of Carlborg $P$. and Kindström D. and Kowalkowski C. (2014), Gremyr I. and Witell L. and Löfberg N. and Edvardsson B. and Fundin A. (2014) investigated the historical aspects of the innovative services development based on the scientific and technological progress; such researchers as Wang $Q$. and Voss C. and Zhao X. and Wang Z. (2015) highlighted the issue of Internet services typology; the scientists Zhuraeva K.A. (2011), Bilgihan A. and Nejad M. (2015), disclosed the essence of innovation in tourism; scientists Huang $Z$. and Benyoucef M. (2013), Nikulin D. and Krasnov S.V. (2017) explored the online commerce issues; such scientists as Castells M. (2001), Baller S. and Dutta S. and Lanvin B. (2016), studied the use of global information technology.

However, the study of the peculiarities of Internet services use by the tourism product consumers in Ukraine is not yet sufficiently covered in the educational and professional literature. All the above proves the relevance of the chosen topic, and therefore determined the choice of research direction.

The main tasks of the article are the study of the peculiarities of Internet services use by the tourism product consumers in Ukraine.

The generalization of data representing the social characteristics of Internet consumers in some regions of Ukraine will allow tourism enterprises to better focus on the needs, requirements and capabilities of the final consumer of the tourism product.

Identification of the main reasons and motives for making online purchases of tourism products by consumers, as well as the identification of barriers that hinder the further development of online commerce and the promotion of online services, will help the tourism industry enterprises to better plan their work for future periods. 


\section{METHODOLOGY}

Without a clear understanding of the social nature of I-customer orientation and its peculiar characteristics, it is impossible to apply the customer-oriented approach correctly and for the good of society. Besides, it seems to be impossible in the absence of results of empirical research including the corporate employees and customers as respondents.

The method of survey is used to conduct an empirical research. There are plans to use a questionnaire-based survey in the Internet to interview the target audience, I-consumers of tourist services and managers of tourist enterprises.

In this manner, one can achieve the values of I-customer orientation of the enterprise as realized by managers and customers, as well as their ideas of just what kind of social customer-oriented technologies would be applied at the enterprises.

The data obtained by employing the method combinations will allow for the analysis of application of I-customer which oriented technologies by tourist enterprises and comparison them with the customer preferences.

\section{RESULTS}

The end of the XX beginning of the XXI century can be called the digital era or the Internet era, which has rapidly and deeply penetrated into all spheres of economy, business and society as a whole. The struggles that exist in the modern world and the technological revolution have a global impact on the service establishments functioning, as well as on the way of services delivery and contact with consumers. This has led to the emergence of such phenomena as the Internet business (the I-business).

The I-business is any business activity in the Internet. It is becoming a new and more and more popular form of realization of one's own business, opening up new opportunities for economic activity in providing online services [3, p.168]. The I-service is meeting the human needs through the Internet from the moment of company contact with the customer by offering the appropriate service.

The virtual form of service provision enables greater standardization and concerns full or partial i-customers service [7, p.124].

The following components of I-business success should be distinguished:

- security is the guarantee of conducting safe operations, including their documentation;

- flexibility is the openness to new products and technologies;

- integration is the communication with customers, partners and suppliers of tools and modern technologies.

These components are intended to lay the groundwork for the latest marketing strategy built between the I-business and I-consumer, that is, a consumer who meets the needs via the Internet, based on feedback.

The I-consumer cannot meet his or her needs without the i-business, and the I-business cannot function without the I-consumer [4, p.72]. Thus, there is a growing need for a comprehensive study of the I-consumption structure in the general context of marketing strategies and I-consumers as the representatives of a society influenced not only by the social and economic but also by the informational factors, in particular the Internet.

Today Internet plays a very important role in the consumer's life, manifesting itself primarily in three areas:

- informational one as a daily source of any information;

- communicational one - via E-mail and various systems of electronic communicators (for example, Skype);

- entertainment one - through accessible web pages, banners and more.

In this context the practical focus of the Internet and mobile technologies on the I-services development, which is one of the important factors of civilizational change, is worth mentioning.

More and more countries support this development as a manifestation of building an information society, focusing on better meeting the needs of society, and improving living standards.

The I-services are increasingly penetrating homes and households, meeting the ever-increasing needs of a modern human being. In turn, the I-consumers become more mature, active and demanding, unlike the ordinary consumer, influencing I-services with their purchasing decisions, joint creation of services etc. [9, p.46].

The I-consumer is defined as a person or organization that consumes goods and services using Internet to facilitate the process of consumer practice [8, p.126]. At the same time, the process of consumption consists of identifying needs, finding consumer solutions, purchasing goods and services, as well as solving topical issues that arise as a result of these steps and their subsequent solution. The I-consumer has access to numerous sources of information, i-products and I-services [11, p.1359].

The understanding of the I-consumer is inseparable from the social background, above all, those social and demographic characteristics that determine its appearance, reflect the background (social) conditions and, in prospect, determine the I-consumer activity level [5, p.375]. In 2010, a media audience research project was set up in Ukraine based on a user-centric approach - Opinion Software Media.

The main objective of the project is to study the web site traffic and the social and demographic profile of their visitors. Based on the analysis of the project data, we conducted a survey of the Internet audience of the tourist services market target consumer.

Table I shows the results of marketing Internet surveys conducted during 2017-2018 in the regions of Ukraine, reflecting the features and level of I-services use. 
Table-I. Ukrainian I-consumer profile, in \% of total number of buyers*, **

\begin{tabular}{|c|c|c|c|c|c|c|c|c|}
\hline \multirow[b]{2}{*}{ Region } & \multicolumn{2}{|c|}{ Sex } & \multicolumn{3}{|c|}{ Age } & \multicolumn{3}{|c|}{$\begin{array}{c}\text { Financial } \\
\text { security }\end{array}$} \\
\hline & $\underset{\mathrm{E}}{\overline{\mathrm{E}}}$ & 音 & ch & 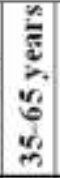 & 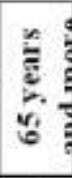 & 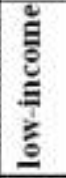 & $\frac{E_{0}}{2}$ & $\stackrel{\Xi}{\mathbb{E}}$ \\
\hline Kharkiv & 18 & 13 & 23 & 19 & 3 & 11 & 13 & 27 \\
\hline Vinnytsia & 14 & 12 & 14 & 9 & 3 & 13 & 17 & 19 \\
\hline Kyiv & 26 & 20 & 28 & 14 & 9 & 26 & 18 & 46 \\
\hline Zhytomyr & 13 & 11 & 13 & 9 & 5 & 6 & 19 & 12 \\
\hline Zakarpattia & 13 & 10 & 19 & 15 & 8 & 5 & 16 & 42 \\
\hline Zaporizhia & 15 & 18 & 22 & 17 & 7 & 3 & 14 & 22 \\
\hline $\begin{array}{l}\text { Dnipropetrovs } \\
k\end{array}$ & 19 & 15 & 23 & 10 & 7 & 5 & 5 & 18 \\
\hline Lviv & 13 & 11 & 14 & 11 & 6 & 8 & 10 & 22 \\
\hline Kherson & 11 & 9 & 12 & 9 & 4 & 10 & 13 & 12 \\
\hline Mykolaiv & 14 & 12 & 16 & 14 & 6 & 7 & 13 & 14 \\
\hline Odesa & 22 & 21 & 22 & 18 & 10 & 24 & 16 & 28 \\
\hline Cherkasy & 14 & 13 & 18 & 13 & 8 & 15 & 15 & 24 \\
\hline
\end{tabular}

*Source: according to the data of the Ministry of

Economic Development, Trade and Agriculture of Ukraine

(excluding data on the Crimea and regions of the JFO area), [1].

**Two methods were used in qualitative research: in depth individual interview and focus group interviews.

As follows from Table I the typical Ukrainian I-consumer is a person under the age of 35 , who belongs to the category of «wealthy» and resides in the Central and Southeastern regions of Ukraine.

Pursuant to our research, the I-consumer, according to his qualitative characteristics, is associated with the person who necessarily uses the Internet and I-services.

The consumer, who is well-informed about the product, its consumer properties and changes, is an important source for enterprises and organizations in creating a further activity strategy [2].

Therefore, tourism enterprises need to take these changes into account when creating appropriate marketing strategies.

The main reasons for the low use of modern I-technologies in Ukraine include being beyond them (for various reasons), as well as the inability to use them. Other reasons for information sharing include the lack or backwardness of an appropriate infrastructure of new technologies, although recognizing them as major and inhibiting factors would be an exaggeration.

Among the main universal reasons that motivate the population to use I-services are: the time-saving; variety of proposals; convenience; overcoming geographical and temporary barriers; finance saving.

In terms of motivational incentives, we investigated the reasons and motives that make the I-users to use the I-consumption (see Table II).
Table II. Reasons and motives for making online-purchases by the regions of Ukraine, \% of total number of purchases*

\begin{tabular}{|c|c|c|c|c|c|}
\hline Region & 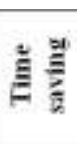 & $\frac{c}{2}$ & है & 恶 & 总祀 \\
\hline Kharkiv & 2,93 & 2.66 & 3.19 & 2,06 & 3,80 \\
\hline Kyiv & 3,53 & 3.56 & 3,64 & 2,72 & 3,80 \\
\hline Vinuntsia & 3,33 & 3,52 & 3,11 & 3,00 & 3,78 \\
\hline $\begin{array}{l}\text { Dnipropetrov } \\
\text { sk }\end{array}$ & 3.19 & 3.53 & 3,69 & 3,15 & 3.87 \\
\hline Odesa & 2,98 & 3,02 & 3.77 & 2,45 & 3,96 \\
\hline $\begin{array}{ll}\text { On } & \text { an } \\
\text { average } & \end{array}$ & 3.19 & 3.25 & 3.48 & $2,6^{7}$ & 3.84 \\
\hline
\end{tabular}

* Source: Based on a survey conducted by I-users. The table shows the results of a 5-point Likert scale survey, where: 1 - is the lowest score, 5 - is the highest score.

As can be seen from Table II, the I-users are focused, first of all, on quick access to the necessary information $(3,84)$. Other important reasons and motives are: convenience, variety of offers, time savings. The lowest rating was taken by the «better financial opportunity» motive offered by online stores compared to travel companies. It is stated that the «quick access to information» motivation received the highest average score (3.96).

The highest rates related to the I-consumption score as a «convenient online shopping tool» are also important $(3,77)$ For example, among the I-users in Dnipropetrovsk region, these figures were 3.87 and 3.69 respectively. For the I-users in Kyiv region, in comparison with the other regions of Ukraine, such features as «variety of offers» and «time saving» were more valuable. In Kharkiv region, the consumers recognize the index «convenience» along with the «quick access to information» more, and the index «better financial conditions than in ordinary shops» less.

According to data analysis of information systems and data processing of the Internet sphere in Ukraine [6], 75\% of respondents recognized the priority of the «possibility of orders at any time». The motives related to «home delivery» $(57 \%)$ and «time saving» $(58 \%)$ shared the second and third places respectively.

The «lower commodity prices» motive took only the fourth place (see Table III).

Table-III. Motives for making online-purchases in Ukraine, \%*

\begin{tabular}{|c|c|c|c|c|}
\hline Motive & 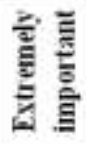 & 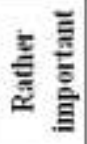 & 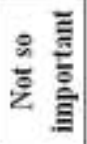 & 高 \\
\hline Order anytime & 62 & 14 & 10 & 14 \\
\hline Home delivery & 57 & 19 & 10 & 14 \\
\hline Time saving & 58 & 19 & 10 & 14 \\
\hline Lower commodity prices & 48 & 23 & 12 & 17 \\
\hline Great availability of goods & 43 & 21 & 15 & 21 \\
\hline Easy comparison of offers & 41 & 26 & 13 & 20 \\
\hline $\begin{array}{l}\text { Lots of information about } \\
\text { products }\end{array}$ & 32 & 28 & 16 & 21 \\
\hline Other & 6 & 3 & 3 & 88 \\
\hline
\end{tabular}

* Source: based on a survey conducted by the I-users. 
Thus, the popular myth of «price importance in online shopping» is rejected by the true indices that are decisive in modern I-consumption, in particular in Ukraine.

As for the Ukrainian tourism market, a number of barriers hinder the further development of i-commerce, namely:

- low public awareness of the I-commerce benefits in the tourism sector;

- potential consumers are not willing to buy tourist products and services, since the quality of their provision cannot be verified;

- distrust of the travel companies and agencies operating on the Internet;

- sale of tours against prepayment only;

- online travel agencies and tour operators often dictate their terms to potential buyers (in case of the service cancellation, no prepayment return is guaranteed);

- possible lack of insurance services;

- lack of a legal field (legislation) designed to regulate the activity of virtual trade, especially with regard to the refund for poor tourist services.

Nowadays, more and more consumers of tourism products are turning to e-commerce, in particular the I-tourism $[12$, p.225]. Of course this means not the virtual emotions about the tours or holidays, but about facilitating the selection and booking of tourist services.

In recent years in Europe the share of online sales of services in tourism has been increasing. In Ukraine, such sales remain short of the similar traditional services of travel companies, but we can speak about the high dynamics of growth in the future.

Some travel services already use the i-commerce, based on the elements of artificial intelligence, which helps to analyze large amounts of data and learn from their own and other people's experience of filling the customer orders.

Personalized services that are most suitable for a particular customer are a strong competitive advantage. It is the artificial intelligence that helps to select such services, since it allows you to process a large amount of data and create a personalized product much faster than the traditional search technologies.

An example of such an application is a personal assistant, a «travel agent» from the Mezi company. With the help of numerous search engines with travel data, Mezi creates a matrix of the «ideal» tourist trip by analyzing the user messages, search queries and other Internet activity. For example, if you are more interested in shops, national parks and at the same time the attractions, the artificial intelligence will be able to make an extraordinary trip easier than an employee trying to choose something suitable from a set of «standard» tours.

Other companies, such as GuestU and SnapTravel services, monitor search queries and messages in the Facebook social network messenger (FB, NASDAQ), allowing you to book personalized travel services via chat. In May 2016 the company-supplier of hotel reservation service Booking.com launched its «smart» chat. This chat can give the client the same information as a travel agent, but much faster. Booking.com is currently conducting a test integration of its chat with the Facebook messenger. Large Travel Operator Expedia Inc. (EXPE, NASDAQ) plans to use artificial intelligence to serve customers.
Thus, Internet technologies are the next stage in the tourism industry development. For example, $75 \%$ of Booking.com customers prefer travel search and booking properties according to individual parameters. Of course, people will continue to work in the tourism sector, for example, in compiling expensive unique trips, or directly interacting with people. In particular, $61 \%$ of Ukrainians want to see not robots, but people at the check-in counters at the airports, and $66 \%$ - at airport security services [1]. However, gradually the role of human in tourism will decrease, and technology and travel companies will receive additional income due to the new opportunities.

The features of using I-services on the example of analytical indices of the tourism sector, according to the results of the conducted research in some regions of Ukraine are given below (see Table IV).

Table-IV. Use of I-tourism services in 2017-2018, \% *

\begin{tabular}{|c|c|c|c|c|c|}
\hline Options for services use & 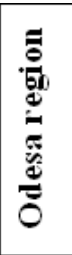 & 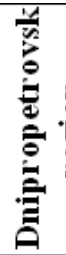 & 爱 & 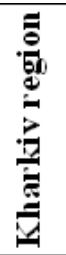 & 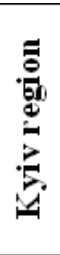 \\
\hline $\begin{array}{l}\text { Use of tourism } \\
\text { obtain the } \\
\text { information }\end{array}$ & $\begin{array}{c}64 \\
2\end{array}$ & $\begin{array}{c}61, \\
3\end{array}$ & $\begin{array}{c}79 \\
2\end{array}$ & $\begin{array}{c}90, \\
1\end{array}$ & $\begin{array}{c}81, \\
0\end{array}$ \\
\hline $\begin{array}{l}\text { Use of travel companies } \\
\text { websites, comparison of } \\
\text { tourist offers }\end{array}$ & $\begin{array}{c}57 \\
5\end{array}$ & $\begin{array}{c}61, \\
3\end{array}$ & $\begin{array}{c}67, \\
0\end{array}$ & $\begin{array}{c}81, \\
0\end{array}$ & $\begin{array}{c}56, \\
2\end{array}$ \\
\hline $\begin{array}{l}\text { Reading blogs related to } \\
\text { tourism, travel, jouneys }\end{array}$ & $\begin{array}{c}50 \\
9\end{array}$ & $\begin{array}{c}52 \\
8\end{array}$ & $\begin{array}{c}62 \\
3\end{array}$ & $\begin{array}{c}79 \\
3\end{array}$ & $\begin{array}{c}51 \\
4\end{array}$ \\
\hline 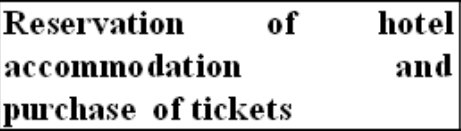 & $\begin{array}{c}32, \\
1\end{array}$ & $\begin{array}{c}49, \\
1\end{array}$ & $\begin{array}{c}\mathbf{5 5} \\
7\end{array}$ & $\begin{array}{c}76 \\
9\end{array}$ & $\begin{array}{c}41, \\
0\end{array}$ \\
\hline Excursion planning & $\begin{array}{c}30, \\
2\end{array}$ & $\begin{array}{c}33, \\
0\end{array}$ & $\begin{array}{c}34 \\
9\end{array}$ & $\begin{array}{c}59, \\
5\end{array}$ & $\begin{array}{c}14, \\
3\end{array}$ \\
\hline $\begin{array}{l}\text { Sales of tourism services and } \\
\text { tourism products }\end{array}$ & $\begin{array}{c}42 \\
8\end{array}$ & $\begin{array}{c}27, \\
8\end{array}$ & $\begin{array}{c}38, \\
1\end{array}$ & $\begin{array}{c}51 \\
7\end{array}$ & $\begin{array}{c}53, \\
6\end{array}$ \\
\hline
\end{tabular}

*Source: based on a survey conducted by the I-users.

In 2018 the share of online sales of tourism services and tourism products in the investigated regions of Ukraine was at least $28 \%$ in Dnipropetrovsk region. The results show that in Kharkiv region I-tourism is the most popular among all the surveyed areas, especially for such positions as the tourism services use $(90.1 \%$ ) (it should be noted that this type of services is used by $81.0 \%$ of respondents); comparison of tourist offers $(81.0 \%)$, reading of tourism blogs $(79.3 \%)$, reservation of hotel accommodation and purchase of tickets (76.9\%). In addition, the I-consumer in Kharkiv region was more oriented to planning his own tours and trips (59.3\%), while Kyiv region occupies the lowest position under this index $(14.3 \%)$.

The data of the conducted research showed a rather high level of Internet network search activity possibilities and its use among the surveyed consumers of tourism product from different regions of Ukraine concerning commercial offers 
through the Internet and their comparison.

The World Tourism Organization (UNWTO) [10] encourages its Member States as well as the developing countries to use the opportunities that make information accessible via Internet. It supports the I-tourism development strategy based on effective tools that enable consumers to identify and purchase quality products, and the suppliers to expand, distribute and manage their offerings globally.

\section{DISCUSSION}

The I-services are not an alternative to the traditional form of selling services, but are its necessary complement. Increase of the I-services use requires new marketing approaches designed to, on the one hand, show the consumers what opportunities a new information medium opens for them, and, on the other hand, to help overcome technical barriers associated with a lack of skills and use of computer and information technology. The index of distrust in information technology and such a mental factor as unwillingness to learn the latest technological advances are also important

The study of the I-services use by the I-consumers of tourism products made it possible to determine the indices that represent the social and demographic characteristics of the I-consumers sphere of some regions of Ukraine. In particular, such indices should be considered: level of culture, society's rules, social classes, geographical area of residence, reference groups, demographic characteristics of the consumer, social status, social and economic indices, psychological profile of the individual, behavioral principles of the consumer etc. One of the important factors influencing the I-consumption model is the standard of living and well-being of the population. All of these factors comply with the multiplicatory principle. In different social conditions, at different time periods, depending on the social model of consumption and the I-consumer status, different factors of influence prevail. They should be evaluated and researched systematically and comprehensively, according to the appropriate methodology.

That is, taking into account various determination factors, it is possible to typologize the determinants and distinguish different patterns of I-consumption (by the activity, type of culture, character of people).

\section{CONCLUSIONS}

As a result of the conducted researches it should be noted that the main reasons and motives for making online purchases of tourism services are:

- time saving;

- variety of offers;

- convenience;

- overcoming geographical and temporary barriers;

- financial saving, etc.

Among the reasons and obstacles to the development of I-commerce and promotion of I-services in the tourism sector are:

- low awareness of the population about the benefits of Internet commerce in the tourism sector;

- inability to check the quality of tourism services;
- distrust of travel companies and agencies operating on the Internet;

- sale of prepaid tours;

- the absence of a legal framework to regulate virtual commerce, especially concerning reimbursement of poor tourism services.

The results of quantitative and qualitative studies on the Internet services use by tourism services consumers in Ukraine make it possible to state that in Kharkiv region the I-tourism is the most popular among all the studied areas, in particular in the field of I-service. In Kharkiv region the I-consumer proved to be more oriented towards planning his own tours and trips, while Kiev region occupies the lowest position by similar index. Thus, in many regions of Ukraine, despite the economic crisis, the projected growth of the I-services development is very optimistic. In the nearest future further growth of I-commerce in tourism and expansion of I-services channels is expected. Similar trends are associated with an increase in the number of I-consumers willing to browse the functional destination of the Internet, which is no longer a way for them to entertain, but also a means of rest and leisure organization.

\section{Practical implications.}

The research findings can be used as a source of information on the behavior of consumers of tourism services in the process of forming innovative marketing strategies for tourism enterprises.

\section{REFERENCES}

1. Analytics and statistics in tourist, 2019. The Ministry of Economy, Trade and Agriculture of Ukraine. Available at: http://www.me.gov.ua/Documents/List?lang=uk-UA\&id =be44a1a7-69b3-4a77-a86a-447499abcdd6\&tag=Analiti ka\&isSpecial=true (accessed 30 September, 2019)

2. Baller, S., Dutta, S., Lanvin, B. The Global Information Technology Report 2016. Innovating in the Digital Economy, $2016 . \quad$ URL: http://www3.weforum.org/docs/GITR2016/WEF_GITR_ Full_Report.pdf (accessed 29 September, 2019)

3. Bilgihan, A. and Nejad, M. Innovation in hospitality and tourism industries. Journal of Hospitality and Tourism Technology, vol. 6, no. 3, pp.167-171, 2015. URL: https://doi.org/10.1108/JHTT-08-2015-0033

4. Castells, M. The Internet Galaxy: Reflections on the Internet, Business, and Society. Oxford University Press, Inc. New York, NY, USA, 2001.

5. Carlborg, P., Kindström, D. and Kowalkowski, C. The evolution of service innovation research: a critical review and synthesis. The Service Industries Journal, vol. 34, no. 5, pp. 373-398, 2014.

6. Internet audience research, 2019. Internet Association of Ukraine. Available

at: https://inau.ua/proekty/doslidzhennya-internetaudytoriyi (accessed 30 September, 2019)

7. Gremyr, I., Witell, L., Löfberg, N., Edvardsson, B. and Fundin, A. Understanding new service development and service innovation through innovation modes. Journal of Business \& Industrial Marketing, Vol. 29 No. 2, pp. 123-131, 2014 
8. Huang, Z. and Benyoucef, M. From e-commerce to social commerce: a close look at design features. Electronic Commerce Research and Applications, vol. 12, no. 4, pp. 246-259, 2013.

9. Nikulin, D.Yu., Krasnov, S.V. Intelligent technology in tourism. Bulletin of the Volga University named after V.N. Tatishchev, vol. 4, no. 22, pp. 45-50, 2017.

10. UNWTO. Sustainable Development of Tourism Conceptual Definition. 2019. Available at: http://unwto.org (accessed 29 September, 2019)

11. Wang, Q., Voss, C., Zhao, X. and Wang, Z. Modes of service innovation: a typology. Industrial Management \& Data Systems, vol. 115, no. 7, pp. 1358-1382, 2015.

12. Zhuraeva, K.A. Innovative technologies in tourism. Geography and Tourism, vol. 14, pp. 224-230, 2011. URL: http://nbuv.gov.ua/UJRN/gt_2011_14_43 